\title{
Article \\ Genetic Diversity and Population Structure of Serbian Barley (Hordeum vulgare L.) Collection during a 40-Year Long Breeding Period
}

\author{
Ljiljana Brbaklić ${ }^{1, *(D)}$, Dragana Trkulja ${ }^{1}$, Sanja Mikić ${ }^{1} \mathbb{1}$, Milan Mirosavljević $^{1}$, Vojislava Momčilović ${ }^{1}$, \\ Branislav Dudić ${ }^{2,3, * \mathbb{D}}$, Lenka Procházková ${ }^{2}$ and Vladimir Aćin ${ }^{1}$ \\ 1 Institute of Field and Vegetable Crops, Maksima Gorkog 30, 21000 Novi Sad, Serbia; \\ dragana.trkulja@ifvens.ns.ac.rs (D.T.); sanja.mikic@ifvens.ns.ac.rs (S.M.); \\ milan.mirosavljevic@ifvcns.ns.ac.rs (M.M.); vojislava.momcilovic@ifvcns.ns.ac.rs (V.M.); \\ vladimir.acin@ifvens.ns.ac.rs (V.A.) \\ 2 Faculty of Management, Comenius University in Bratislava, 82005 Bratislava, Slovakia; \\ lenka.prochazkova@fm.uniba.sk \\ 3 Faculty of Economics and Engineering Management, University Business Academy, 21000 Novi Sad, Serbia \\ * Correspondence: ljiljana.brbaklic@ifvens.ns.ac.rs (L.B.); branislav.dudic@fm.uniba.sk (B.D.); \\ Tel.: +381-214898215 or +381-642097667 (L.B.); +421-250-117-403 (B.D.)
}

Citation: Brbaklić, L.; Trkulja, D.; Mikić, S.; Mirosavljević, M.;

Momčilović, V.; Dudić, B.;

Procházková, L.; Aćin, V. Genetic

Diversity and Population Structure of

Serbian Barley (Hordeum vulgare L.) Collection during a 40-Year Long Breeding Period. Agronomy 2021, 11, 118. https://doi.org/10.3390/ agronomy11010118

Received: 8 November 2020

Accepted: 7 January 2021

Published: 9 January 2021

Publisher's Note: MDPI stays neutral with regard to jurisdictional clai$\mathrm{ms}$ in published maps and institutional affiliations.

Copyright: (C) 2021 by the authors. Licensee MDPI, Basel, Switzerland. This article is an open access article distributed under the terms and conditions of the Creative Commons Attribution (CC BY) license (https:// creativecommons.org/licenses/by/ $4.0 /)$.

\begin{abstract}
Determination of genetic diversity and population structure of breeding material is an important prerequisite for discovering novel and valuable alleles aimed at crop improvement. This study's main objective was to characterize genetic diversity and population structure of a collection representing a 40-year long historical period of barley (Hordeum vulgare L.) breeding, using microsatellites, pedigree, and phenotypic data. The set of 90 barley genotypes was phenotyped during three growing seasons and genotyped with 338 polymorphic alleles. The indicators of genetic diversity showed differentiation changes throughout the breeding periods. The population structure discriminated the breeding material into three distinctive groups. The principal coordinate analysis grouped the genotypes according to their growth habit and row type. An analysis of phenotypic variance (ANOVA) showed that almost all investigated traits varied significantly between row types, seasons, and breeding periods. A positive effect on yield progress during the 40 -year long breeding period could be partly attributed to breeding for shorter plants, which reduced lodging and thus provided higher yield stability. The breeding material revealed a considerable diversity level based on microsatellite and phenotypic data without a tendency of genetic erosion throughout the breeding history and implied dynamic changes in genetic backgrounds, providing a great gene pool suitable for further barley improvement.
\end{abstract}

Keywords: agronomic traits; breeding history; genetic variability; Hordeum vulgare L.; microsatellites; pedigree; population differentiation

\section{Introduction}

Cultivated barley (Hordeum vulgare L.) is one of the most important crops, ranking as the fourth most produced cereal, after wheat, maize, and rice. It is one of the most adapted crops to an exceptionally wide range of diverse environmental conditions, grown in more than 100 countries worldwide [1]. A recent stagnation of barley production in Europe has primarily been caused by climate change, socio-economic reasons, and agronomic reasons. Unchanged barley production could be a result of a $15 \%$ decline in area, offset by moderate yield growth and increased yield variability (http:/ / faostat.fao.org). Some of these trends over Europe may have been caused by recent climate changes. Nevertheless, it is unlikely that the barley production has reached its maximum genetic yield potential. However, the frequent use of narrow genetic pools in breeding programs could aggravate this phenomenon. 
Plant breeding is based on the effective shuffling of genetic variation aimed at generating new and improved combinations of alleles, and assembling them in a single superior genetic background. A sufficient level of genetic diversity is a critical component in successful breeding programs. Nonetheless, modern intensive plant breeding practices led to a reduction of genetic diversity and formation of a genetic bottleneck as a consequence of relatively narrow germplasm pools used throughout breeding processes [2]. Aside from modern breeding, the long-term domestication history also greatly impacted the trend of the loss of genetic diversity [3]. This huge decrement of genetic variability could hinder breeding endeavors in coping with current and future challenges of biotic and abiotic stresses [4].

Numerous studies revealed different levels of genetic diversity in accessions from various geographic origins [5-10]. A considerably higher level of genetic diversity and the number of haplotypes was found in wild barley accessions and landraces compared to present-day cultivated barley genotypes [11-13]. The level of genetic diversity considering allelic richness, gene diversity, and percentage of unique alleles in cultivated barley genotypes ranged from very low in regions of Europe [14] to extremely high compared to other continents $[7,15,16]$. In addition, barley genotypes can be divided into groups according to the spike morphology, intended use, and seasonal growth habit, which is the result of strong selection for different target traits such as yield, malting quality, resistance to diseases, and tolerance to abiotic stresses $[17,18]$. The factors with the largest effects on population structure in plants were determined as mutations, human and/or environmental selection, genetic drift, mating system, and growth habit [19]. In the case of barley, these factors were manifested in a mutation of an ancestral wild-type two-rowed barley resulting in a recessive six-rowed type after domestication [20], geographical segregation and separate breeding of the two- and six-rowed types, and their adaptation to different environments leading to differentiation of the spring and winter forms [21].

The knowledge of allelic composition of parental lines could facilitate breeding for certain agroclimatic regions [10]. Among various methods based on morphological, physiological, and biochemical information in the last decades, DNA-based markers are routinely used for detection of polymorphism, marker-assisted selection, fingerprinting, diversity studies, and many other molecular and genetic analyses [22]. The level of genetic diversity can be estimated with pedigree data; however, one of its major deficiencies is a lack of reliability of pedigree information due to insufficient, faulty, or incorrect data in the available literature. Assessment of genetic diversity directly on the DNA level by estimation of the proportion of alleles identical by state [19] could be of great assistance during the transfer of desired combinations of disease resistance, quality, or yield-related traits into the existent modern genotypes [23]. After several decades of applying molecular markers in different genetic studies, microsatellites are still being used for crop improvement in breeding programs due to their high levels of polymorphisms, codominant and multiallelic nature, an unambiguous designation of alleles, relative assay simplicity, high reproducibility, and stability [21,22,24,25]. The value of simple sequence repeats (SSRs), as a powerful means for genome mapping, variety identification, and genetic analyses in barley breeding, has been highlighted in many studies [6-8,23,26-28]. Estimation of genetic diversity by SSR markers associated with specific traits may reveal the real effects of selection during modern breeding compared to detecting polymorphism in non-coding genomic regions [29,30]. The discovery of highly sophisticated breeding tools and access to a broad genetic diversity of barley are two main cornerstones for increasing gain from selection and will probably remain the major key factors for further breeding progress.

Although the presence of valuable genetic diversity in breeding material is one of the main prerequisites for creation of superior yield varieties with high-quality characteristics, limited information is available on genetic diversity of barley genotypes from central and southeast Europe that are widely used in Serbian breeding programs, and it is mostly based on morphological and physiological traits. The use of these genetic resources in barley breeding started more than 70 years ago with collecting local landraces, followed by the introduction of foreign varieties well-adapted to the local agroecological conditions and 
development of modern varieties [31]. In addition to the considerable achievements during barley breeding history, better insight into genetic diversity on a phenotypic and, especially, on a molecular level is crucial for further breeding improvements.

The main aims of this study are to determine genetic diversity and population structure of a representative barley germplasm using SSR markers, pedigree, and phenotypic data, to compare genetic diversity of three main historical breeding periods, including the diversity between different groups of varieties, and to validate the suitability of the collection for further quantitative trait studies.

\section{Materials and Methods}

The barley collection of the Institute of Field and Vegetable Crops (IFVCNS) in Novi Sad, Serbia, comprises more than 700 winter and 400 spring barley varieties and elite breeding lines. From this collection, a core set of representative 90 genotypes, originating from Bulgaria, Czech Republic, Croatia, France, Germany, Hungary, Romania, and Serbia, was selected based on their row type, seasonal growth habit, and good adaptability to environmental conditions of central and southeastern Europe, for phenotypic and molecular characterization. All the genetic materials were obtained from the IFVCNS collection, which were adapted to wide geographical regions across the country (Table 1). This representative panel consisted of varieties released from the early 1970s until 2012. The spring barley varieties NS Vujan, NS Marko, and NS Mile were included in the field trials in 2011 and 2012 as experimental lines, before their official release in fall 2012. Based on growth habit and row type, the panel represented 36 winter two-rowed, 35 winter six-rowed, and 19 spring two-rowed barley genotypes. The spring six-rowed genotypes were not represented in the panel. The lack of industrial need for the spring six-rowed barley in this part of southeast Europe has led to its absence on the market and subsequently in breeding programs and commercial production.

For molecular analyses, total genomic DNA was extracted from a young leaf seedling of each of the 90 genotypes using a modified Cetyl trimethylammonium bromide (CTAB) method [32]. PCR amplifications were performed according to the protocol outlined by Röder et al. [33]. Fifty SSR markers with their primers and annealing temperatures were obtained from the GrainGenes database (Table S1). The selection of markers was made based on their associations with important agronomic traits and their even distribution along all seven chromosomes: $1 \mathrm{H} \mathrm{(7),} 2 \mathrm{H} \mathrm{(8),} \mathrm{3H} \mathrm{(6),} \mathrm{4H} \mathrm{(7),} \mathrm{5H} \mathrm{(7),} \mathrm{6H} \mathrm{(7),} \mathrm{and} \mathrm{7H} \mathrm{(8).}$ PCR was performed in a reaction mixture of $10 \mu \mathrm{L}$ containing $30 \mathrm{ng}$ of template DNA, $1 \times$ PCR buffer, $2 \mathrm{mM} \mathrm{MgCl} 2,0.2 \mathrm{mM}$ of each deoxynucleotide, 5 pmol of each fluorescently labelled forward and unlabeled reverse primers, and 1 unit of Taq polymerase (Applied Biosystems, Foster City, CA, USA). The amplification protocol included initial denaturation step, $5 \mathrm{~min}$ at $94{ }^{\circ} \mathrm{C}$, followed by 35 cycles with $30 \mathrm{~s}$ at $94{ }^{\circ} \mathrm{C}, 45 \mathrm{~s}$ at annealing temperature $\left(55,58,60\right.$ or $\left.62{ }^{\circ} \mathrm{C}\right)$ and an extension for $45 \mathrm{~s}$ at $72{ }^{\circ} \mathrm{C}$, with a final extension step of $10 \mathrm{~min}$ at $72{ }^{\circ} \mathrm{C}$. After PCR procedure optimization, the obtained products were determined using fragment analysis on Genetic Analyzer 3130 (Applied Biosystems, Foster City, CA, USA) and analyzed in Gene Mapper software version 4.0 (Applied Biosystems, Foster City, CA, USA). The reaction volume of $10 \mu \mathrm{L}$ consisted of $2 \mu \mathrm{L}$ of mixed differently-labelled PCR products, $0.2 \mu \mathrm{L}$ GeneScan $500 \mathrm{LIZ}$ as a size standard and $7.8 \mu \mathrm{L}$ of Hi-Di. For each microsatellite and barley group, the parameters of genetic diversity were obtained in GeneAlEx software 6.5 (The Australian National University, Canberra, Australia) [34], namely, the number of detected alleles per locus, the number of effective alleles, Shannon's information index, the number of private alleles, polymorphic information content (PIC), observed heterozygosity, unbiased expected heterozygosity, Wright fixation index, and allelic richness. The PIC value of the individual markers was used to evaluate the diversity level of each SSR marker using formula: PIC $=1-\sum(\mathrm{pij})^{2}$, where pi represents frequency of $j$ th allele for marker i. Allelic richness was calculated as the total allele count within the group divided by the group size. The number of private alleles represented the number of alleles unique to a single group. 
Table 1. Names, pedigrees, country of origin, row type, growth habit, and the year of release of the 90 barley genotypes.

\begin{tabular}{|c|c|c|c|c|c|c|}
\hline No & Genotype & Pedigree Data & Origin & RT & GH & Year \\
\hline 1 & Amethyst & Domen/4/Valt/H.jub//Voldagsen/3/Diamant & CZE & 2 & W & 1973 \\
\hline 2 & Sonja & Tria/Malta & DEU & 2 & W & 1974 \\
\hline 3 & Novosadski 183 & Ager/Emir & SRB & 2 & W & 1977 \\
\hline 4 & Victoria & $\mathrm{N} / \mathrm{A}^{1}$ & ROM & 2 & W & 1977 \\
\hline 5 & Novosadski 299 & Fr33/NS.190 & SRB & 2 & W & 1983 \\
\hline 6 & Sonate & Sonja/Firlbeck Strain & DEU & 2 & W & 1983 \\
\hline 7 & Sladoran & Alpha/Mursa & $\mathrm{CRO}$ & 2 & W & 1984 \\
\hline 8 & Novosadski 307 & Fr33/NS.185-2 & SRB & 2 & W & 1984 \\
\hline 9 & Perun & HE 1728/Karat & CZE & 2 & $\mathrm{~W}$ & 1987 \\
\hline 10 & Panonac & Alpha/Osk. 3.145-77 & $\mathrm{CRO}$ & 2 & W & 1987 \\
\hline 11 & Novosadski 323 & NS.185-2/Fr33//Osj.goli/3/NS.185-2/4/Sonja & SRB & 2 & $\mathrm{~W}$ & 1988 \\
\hline 12 & Novosadski 331 & NS. $185-2 / 2 *$ Fr33 & SRB & 2 & W & 1989 \\
\hline 13 & Regina & Labea/Marinka & DEU & 2 & W & 1995 \\
\hline 14 & Tiffany & Labea/Marinka & DEU & 2 & W & 1995 \\
\hline 15 & Novosadski 519 & Rodnik/Corona & SRB & 2 & W & 1998 \\
\hline 16 & Novosadski 525 & NS Ranij-1/Novo.293//NS.327/3/Sladoran & SRB & 2 & W & 1999 \\
\hline 17 & KH Korsó & KA-386-007/Rex & HUN & 2 & $\mathrm{~W}$ & 1999 \\
\hline 18 & Novosadski 529 & OJK 8-82/Novo.293//Sladoran & SRB & 2 & $\mathrm{~W}$ & 1999 \\
\hline 19 & Vanessa & Br.652h/Br.1201a//Astrid & DEU & 2 & W & 2000 \\
\hline 20 & Novosadski 535 & L.107-87/Sladoran & $\mathrm{SRB}$ & 2 & $\mathrm{~W}$ & 2000 \\
\hline 21 & Boreale & Bengal/Angora & FRA & 2 & W & 2000 \\
\hline 22 & Novosadski 565 & Sonate/OSK.5.197-10.85 & SRB & 2 & $\mathrm{~W}$ & 2003 \\
\hline 23 & Novosadski 581 & Sonate/Novo.331 & SRB & 2 & W & 2005 \\
\hline 24 & Novosadski 583 & NS.327/Kaskade/ / Novo.295 & SRB & 2 & W & 2005 \\
\hline 25 & Novosadski 589 & Sonate/NS.525 & SRB & 2 & W & 2006 \\
\hline 26 & Novosadski 593 & Nov225/Zone & SRB & 2 & W & 2007 \\
\hline 27 & NS 500-0601 & NS150/NS.525 & SRB & 2 & W & 2008 \\
\hline 28 & NS 500-0602 & Irla/NS.525 & SRB & 2 & W & 2008 \\
\hline 29 & NS 500-0701 & Novo.525/KM.914 & SRB & 2 & $\mathrm{~W}$ & 2009 \\
\hline 30 & NS 500-0702 & $\mathrm{N} / \mathrm{A}$ & SRB & 2 & W & 2009 \\
\hline 31 & NS Pinon & $\mathrm{N} / \mathrm{A}$ & SRB & 2 & W & 2010 \\
\hline 32 & NS 500-0802 & Marylin/Sonate//Novosadski 525 & SRB & 2 & W & 2010 \\
\hline 33 & NS 500-0901 & KG.8-4/Novo.299//Novosadski 183 & SRB & 2 & W & 2010 \\
\hline 34 & NS 500-0902 & Novosadski 525/Korso & SRB & 2 & W & 2010 \\
\hline 35 & NS 500-1001 & Novo.293//Sonate/NS.525 & SRB & 2 & W & 2010 \\
\hline 36 & NS 500-1002 & NS.151/NS.27 & SRB & 2 & $\mathrm{~W}$ & 2010 \\
\hline 37 & Favorit & Diamant/Firlb.Union & $\mathrm{CRO}$ & 6 & $\mathrm{~W}$ & 1973 \\
\hline 38 & Novosadski 27 & Ceres/Jumbo & SRB & 6 & $\mathrm{~W}$ & 1973 \\
\hline 39 & Robur & Ager/Grignon//Ares & FRA & 6 & W & 1973 \\
\hline 40 & Antares & Ager $/ 2 *$ Grignon $/ 3 /$ Ares & FRA & 6 & W & 1974 \\
\hline 41 & Novosadski 150 & Ceres/Engelen Dea//Leon & SRB & 6 & W & 1976 \\
\hline 42 & Plaisant & Ager/Nymphe & FRA & 6 & W & 1979 \\
\hline 43 & Novosadski 313 & Dura /2*NS.150 & SRB & 6 & W & 1987 \\
\hline 44 & Novosadski 321 & NS.272/Novosadski 27 & SRB & 6 & W & 1988 \\
\hline 45 & Novosadski 329 & Novo.4082/3*Novosadski 27 & $\mathrm{SRB}$ & 6 & W & 1990 \\
\hline 46 & Botond & KFD-4/K-79-4 & HUN & 6 & W & 1991 \\
\hline 47 & Gotic & Robur/Athene//FDE7926-18 & FRA & 6 & W & 1991 \\
\hline 48 & Novosadski 701 & Aksamit/NS.185-2/ /N027 & SRB & 6 & W & 1991 \\
\hline 49 & Novosadski 703 & Novo.150/Riso Mutant 1508//Novo.27 & SRB & 6 & W & 1992 \\
\hline 50 & Galeb & L.2-79/NS.305 & SRB & 6 & $\mathrm{~W}$ & 1993 \\
\hline 51 & Veslec & 102//121/Karnobat & BLG & 6 & W & 1994 \\
\hline 52 & Panagon & No.4074-79/Ruen//M-20-H & BLG & 6 & $\mathrm{~W}$ & 1994 \\
\hline 53 & Epona & Borwina/Plaisant//Gaulois & FRA & 6 & W & 1998 \\
\hline 54 & Grand & $\mathrm{N} / \mathrm{A}$ & SRB & 6 & $\mathrm{~W}$ & 2002 \\
\hline 55 & Novosadski 737 & Plaisant/Galeb & SRB & 6 & W & 2002 \\
\hline 56 & Nonius & Plaisant/Novo.313 & SRB & 6 & W & 2003 \\
\hline 57 & Ozren & Galeb/Botond & SRB & 6 & W & 2004 \\
\hline 58 & Javor & NS 27/Novo.313 & SRB & 6 & $\mathrm{~W}$ & 2004 \\
\hline
\end{tabular}


Table 1. Cont

\begin{tabular}{|c|c|c|c|c|c|c|}
\hline No & Genotype & Pedigree Data & Origin & RT & GH & Year \\
\hline 59 & Atlas & NS 717/Botond & SRB & 6 & $\mathrm{~W}$ & 2005 \\
\hline 60 & Sremac & Gotic/Novo.150 & SRB & 6 & W & 2007 \\
\hline 61 & Leotar & Gotic/Tamaris & SRB & 6 & W & 2007 \\
\hline 62 & Cer & Botond/Novo.150 & SRB & 6 & W & 2008 \\
\hline 63 & Rudnik & Gtk1/Tamaris & SRB & 6 & $\mathrm{~W}$ & 2009 \\
\hline 64 & Jaram & Robur/NS.717 & SRB & 6 & W & 2010 \\
\hline 65 & Pančevac & Gotic/NS.721//Novosadski 313 & SRB & 6 & W & 2010 \\
\hline 66 & NS Krajišnik & Gotic/Tamaris & SRB & 6 & $\mathrm{~W}$ & 2010 \\
\hline 67 & NS Majur & Gotic/NS.721 & SRB & 6 & W & 2010 \\
\hline 68 & NS 700-0901 & Gotic/Tamaris & SRB & 6 & $\mathrm{~W}$ & 2010 \\
\hline 69 & NS 700-0902 & NS.723//Radical/Birgit & SRB & 6 & W & 2010 \\
\hline 70 & NS 700-1001 & Robur/NS.717 & SRB & 6 & $\mathrm{~W}$ & 2010 \\
\hline 71 & NS 700-1002 & Gotic/Tamaris & SRB & 6 & W & 2010 \\
\hline 72 & Novosadski 292 & NS.38/Emir//Union & SRB & 2 & $S$ & 1980 \\
\hline 73 & Novosadski 294 & NS.39/Emir//Union & SRB & 2 & $S$ & 1983 \\
\hline 74 & Novosadski 301 & NS.127/Union & SRB & 2 & S & 1985 \\
\hline 75 & Novosadski 310 & NS.96/Emir//Fr 33 & SRB & 2 & $S$ & 1994 \\
\hline 76 & Viktor & Akka/2*NS.96//2*NS.185/3/Spartan/4/NS.297 & SRB & 2 & S & 2001 \\
\hline 77 & Novosadski 448 & Cork/Hind & SRB & 2 & S & 2001 \\
\hline 78 & Novosadski 456 & Osk.5.241-1-83/Menuet//Viktor & SRB & 2 & S & 2002 \\
\hline 79 & Novosadski 488 & Novosadski 294/Alva//NS 316 & SRB & 2 & $\mathrm{~S}$ & 2003 \\
\hline 80 & Novosadski 462 & Fj.8168-85/Menuet & SRB & 2 & $S$ & 2006 \\
\hline 81 & Golijat & Condor/CDC Down & SRB & 2 & $\mathrm{~S}$ & 2009 \\
\hline 82 & NS 400-0701 & $\mathrm{N} / \mathrm{A}$ & SRB & 2 & $S$ & 2009 \\
\hline 83 & NS 400-0702 & $\mathrm{N} / \mathrm{A}$ & SRB & 2 & $S$ & 2010 \\
\hline 84 & NS 400-0801 & $\mathrm{N} / \mathrm{A}$ & SRB & 2 & $S$ & 2010 \\
\hline 85 & NS 400-0802 & $\mathrm{N} / \mathrm{A}$ & SRB & 2 & $S$ & 2010 \\
\hline 86 & NS 400-0901 & $\mathrm{N} / \mathrm{A}$ & SRB & 2 & $\mathrm{~S}$ & 2010 \\
\hline 87 & NS 400-0902 & $\mathrm{N} / \mathrm{A}$ & SRB & 2 & $\mathrm{~S}$ & 2010 \\
\hline 88 & NS Vujan & NS 434/Alexis & SRB & 2 & $S$ & 2012 \\
\hline 89 & NS Marko & Jelen/TP 129 & SRB & 2 & $S$ & 2012 \\
\hline 90 & NS Mile & NS 422/Alexis//Gimpel/Pek & SRB & 2 & $S$ & 2012 \\
\hline
\end{tabular}

${ }^{1}$ N/A—not available, RT—row type, GH—growth habit. $2^{*}$ - two backcrosses with the following genotype, $3^{*}$-three backcrosses with the following genotype. CZE-Czech Republic, DEU—Germany, SRB — Serbia, ROM-Romania, CRO-Croatia, HUN—Hungary, FRA-France, BLG-Bulgaria; W-winter, S-spring.

The population structure of 90 barley genotypes was inferred by Bayesian statistics model implemented in the program Structure v.2.3.4 (Stanford University, Stanford, CA, USA) [35]. The algorithm was performed using admixture model with 10 runs for 2 to 10 assumed groups using 100,000 Markov chain repetitions after a burn-in period of 100,000 iterations. The most probable number of clusters was estimated by plotting the estimated likelihood values the $\operatorname{Ln} \operatorname{Pr}(\mathrm{X} \mid \mathrm{K})$ and by calculating the delta $\mathrm{K}(\Delta \mathrm{K})$ model, as an ad hoc statistic based on the rate of change in the log probabilities between successive assumed number of groups (K) developed by Evanno et al. [36]. To determine the true number of groups that best fit the data, likelihood values across multiple values of $\mathrm{K}$ were compared and visualized by the software Structure harvester v.0.6.94 [37] and reported as multiple modes from Clumpak results within replicate runs for given K [38]. A cut-off limit of $50 \%$ was used to assign each genotype to an individual cluster. In order to verify the results obtained with Structure and examine the genetic relationships among the genotypes, a principal coordinate analysis ( $\mathrm{PCoA}$ ) based on molecular data was performed using covariance matrix with standardized data in the program GeneAlex 6.5 (The Australian National University, Canberra, Australia) [34], considering the whole population and the row type groups individually. An analysis of molecular variance (AMOVA) was performed on the clusters obtained in the program Structure to assess the population differentiation in the software GeneAlex 6.5 (The Australian National University, Canberra, Australia) [34]. 
The pedigree data were obtained from the Barley pedigree catalogue (http:/ / genbank. vurv.cz/barley/pedigree/pedigree.asp) and from available breeders' records (Table 1). For pedigree analysis, the coefficient of co-ancestry between genotypes was calculated using the Winkin2 program (Agriculture and Agrifood Canada, Ottawa, ON, Canada) [39] obtained from the authors upon request. The coefficient of co-ancestry was assumed to range from 0 , in the absence of any degree of relatedness, to 1 , which explained the maximum degree of kinship. The obtained kinship matrix was transformed into a distance matrix. The Mantel test was used to determine a correlation between the genetic similarity matrix based on SSRs and the pedigree matrix in the program GeneAlex 6.5 (The Australian National University, Canberra, Australia) [34].

The field experiment was performed at the experimental site Rimski šančevi $\left(45^{\circ} 20^{\prime} \mathrm{N}\right.$, $19^{\circ} 51^{\prime}$ E, $84 \mathrm{~m}$ a.s.1.), Serbia. The experimental trials were conducted in a randomized complete block design, sowing in three replications (blocks). The sowing date was conducted on 5, 8, and 10 October for winter varieties, and on 16, 8, and 20 March for spring varieties, during three growing seasons of 2010-11, 2011-12, and 2012-13, respectively. The plot size was $1 \mathrm{~m}$ wide and $5 \mathrm{~m}$ long with $0.2 \mathrm{~m}$ spacing between rows. The block sizes were $215 \mathrm{~m}^{2}$, $209 \mathrm{~m}^{2}$, and $113 \mathrm{~m}^{2}$, for two-rowed winter, sixed-rowed winter, and two-rowed spring barley varieties, respectively, with $1 \mathrm{~m}$ between each block. Eight morphological and agronomical important traits were evaluated, namely heading date (HD), flowering time (FT), stem height (SH), spike length (SL), grains number per $\mathrm{m}^{2}(\mathrm{GN})$, hectoliter weight (HW), thousand grain weight (TGW), and yield (YLD). Heading date and flowering time were recorded as the number of days from the seedling's emergence until spikes emerged out of the flag leaf sheaths and the first anthers were visible, respectively, on $50 \%$ of plants on the plot. Stem height was measured from the ground to the spike base, while spike length was measured without the awns. Multivariate (MANOVA), univariate analysis of phenotypic variance (ANOVA) and Tukey's multiple comparison test were performed in the statistical software R project [40]. Non-sample size dependent type III ANOVA was used to address the unequal number of observations in each group. The partial eta-square was used as a measure of effect size for MANOVA and ANOVA [41]. The Mantel test was used to determine the correlation between SSRs and phenotypic similarity matrices in the program GeneAlex 6.5 (The Australian National University, Canberra, Australia) [34].

\section{Results}

Out of 50 primer pairs used to evaluate genetic diversity of 90 varieties, 48 microsatellites produced a clear and polymorphic band pattern covering all linkage groups, while two were monomorphic. Allelic variants with allele frequencies below 1\% were excluded from further analysis. The molecular diversity parameters implied a considerable variability in the barley collection. A total of 338 polymorphic alleles were detected with an average of 6.76 alleles per locus. The average number of alleles per locus ranged from 1 , for locus Bmac0030 and Bmag0223, to 16, for Bmag0225 (Table S2). The chromosome $4 \mathrm{H}$ had the highest number of detected allelic variations. The number of effective alleles varied from 1 to 9.5, with a mean of 3.6. The Shannon's information index was the highest in locus AWBMS56 and the lowest in locus GBM1164. Observed heterozygosity ranged from 0 to 0.067. The smallest PIC value except monomorphic loci (0.166) was observed in the locus GBM1164, while the highest PIC value (0.895) was determined in the locus AWBMS56. The average PIC was 0.625 in all analyzed loci, while only seven loci had the PIC value less than 0.5. Wright fixation index values were high, ranging from 0.868 to 1.000 . The presence of null alleles was observed in two loci (Bmag0120 and Bmag0613). Structure runs were performed for $K=2$ to $K=10$ based on the 50 SSR data. $\operatorname{Ln} \operatorname{Pr}(X \mid K)$ values increased sharply until $K=4$, following which the increase was slow without reaching the plateau. The Clumpak identified the highest $\ln \operatorname{Pr}(X \mid K)$ value for $K=9$ as the most appropriate number of clusters in this collection (Figure S1). The primary division at $\mathrm{K}=2$ was observed mainly between winter (orange) and spring type (bright blue) (Figure 1). The third group $(\mathrm{K}=3)$ comprised of genotypes differing in growth habit and row type 
marked with orange (W2R), bright blue (W6R), and purple (S2R) colors. Within $K=4$, the genotypes mostly originating from France, Germany, and Hungary were separated in a distinct cluster (dark green). These genotypes were additionally divided into two new clusters generally based on the row type $(K=5)$. The next clusters were obtained from the spring genotypes, where varieties mostly from the third breeding period were singled out into a new sixth group $(K=6)$. The seventh $(K=7)$ emerged from the two-rowed winter group, comprising some varieties from the first breeding period. Several six-rowed varieties mostly from the second breeding period were further differentiated into a new cluster $(K=8)$. The ninth subcluster $(K=9)$ could be explained by the first, second, and third breeding periods detected in spring varieties, although the division was imprecise and not clear-cut. The results of population structure obtained with Evanno's principal model showed that analyzed genotypes could be distributed into three separated clusters (Figure S2), which correspond to the classification based on their seasonal growth habit and row type.

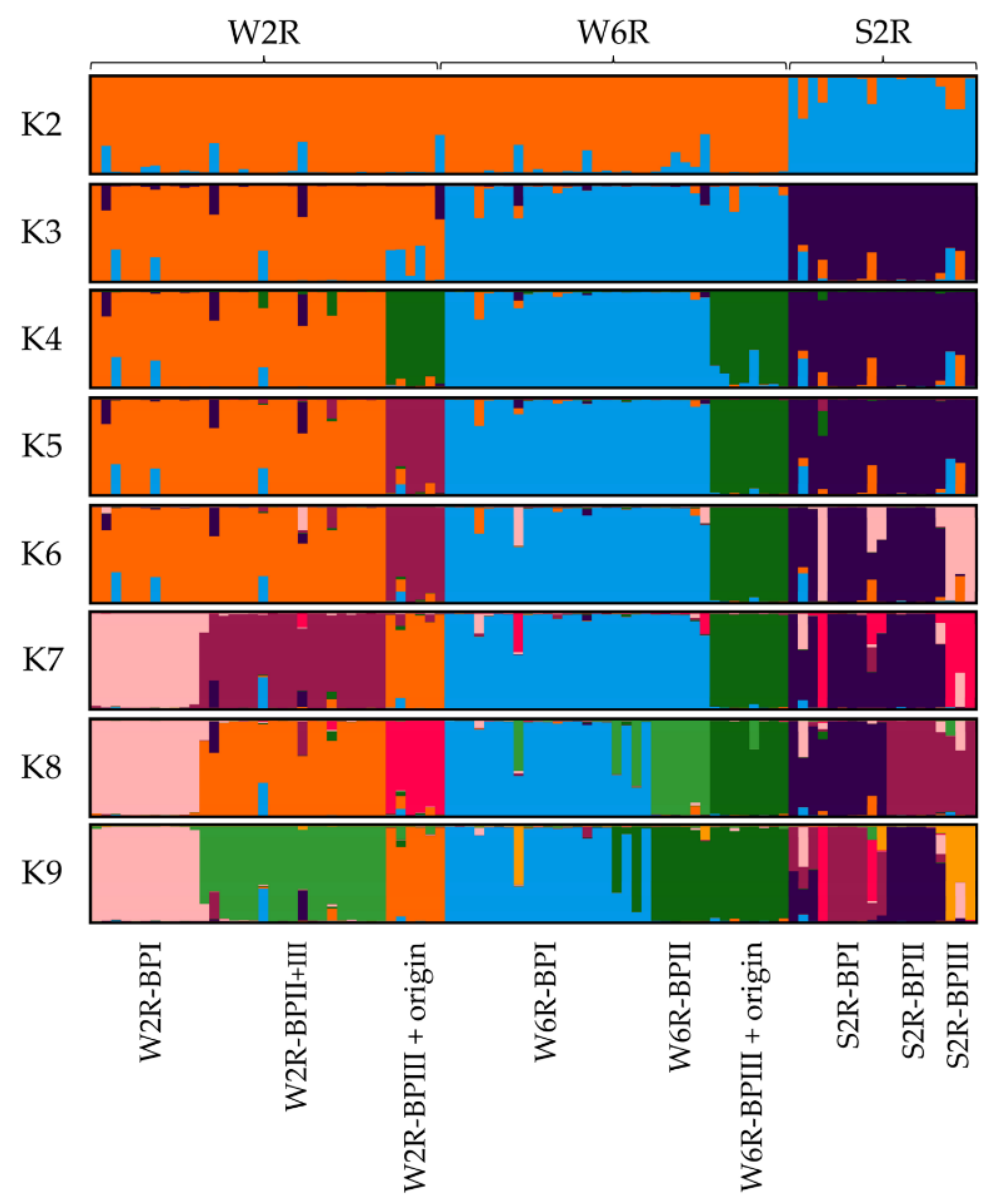

Figure 1. Inferred structure of 90 barley genotypes estimated with Clumpak distruct analysis. Each variety is represented by a vertical line which is divided into $\mathrm{K}$ colored segments proportional to the likelihood of its membership to the assigned cluster from $K=2$ to $K=9$. W2R-two-rowed winter genotypes, W6R—six-rowed winter genotypes, S2R—two-rowed spring genotypes, BPI-the first breeding period, BPII—the second breeding period, BPIII—the third breeding period.

The PCoA revealed genetic differentiation of the barley genotypes also into three clusters clearly divided according to their row type and growth habit (Figure 2). The first two main coordinates accounted for over $35 \%$ of total molecular variation. The first coordinate separated most of the winter two-rowed barley genotypes from the other two groups, whereas the second principal coordinate additionally split winter six-rowed barley 
from the spring two-rowed genotypes. The clustering of the barley genotypes by the PCoA corresponded to the groups determined by the structure analysis.

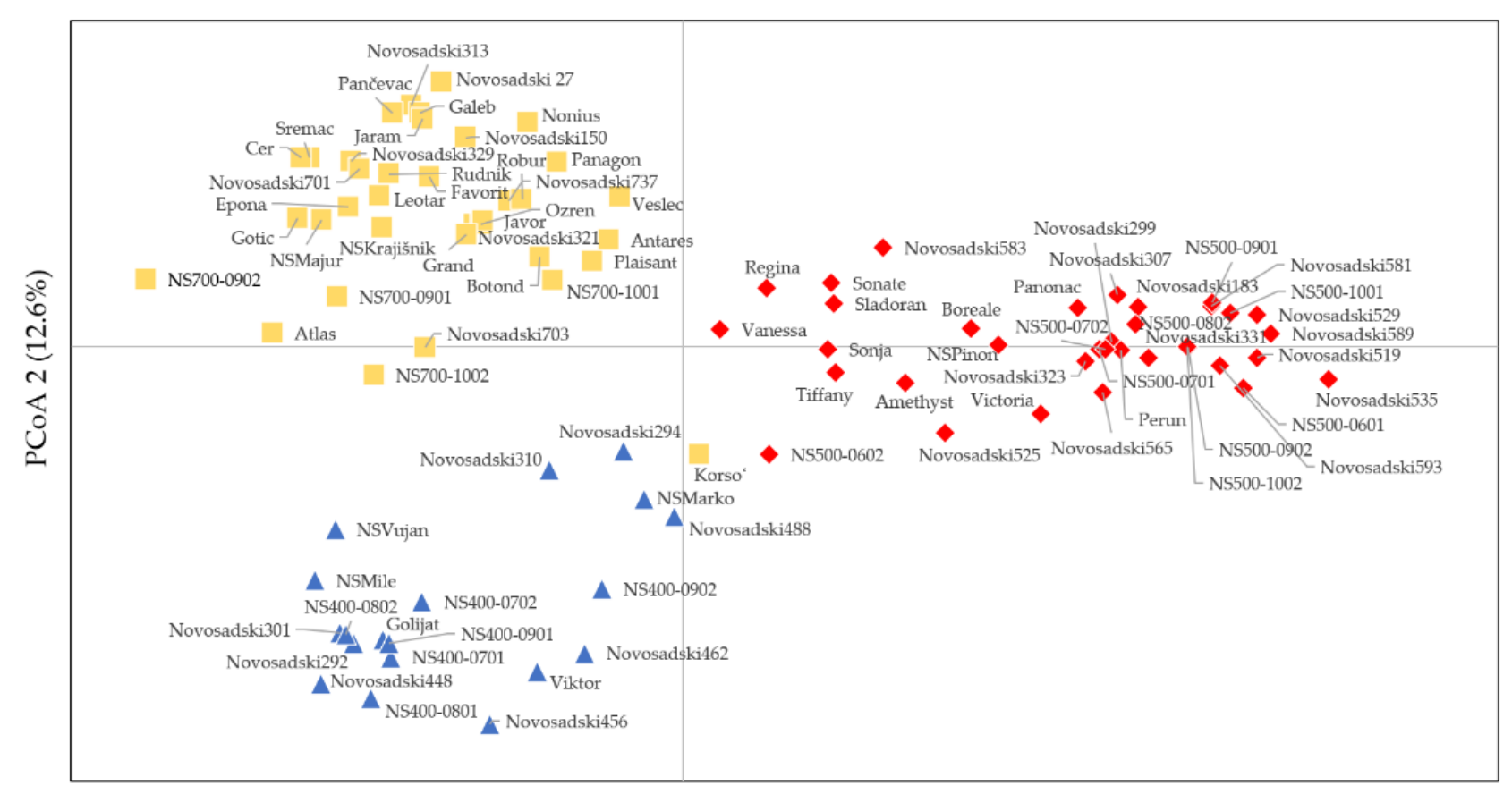

PCoA $1(23.6 \%)$

Figure 2. Principal coordinate analysis of 90 barley genotypes based on microsatellite data. Red diamond-winter two-rowed barley; yellow square—winter six-rowed barley; blue triangle—spring two-rowed barley.

Taking into account different year of release of the analyzed varieties, three partly overlapping groups could be noticed, reflecting three different breeding periods (Figure 3). The first group consisted of 24 varieties released from 1973 to 1990 . The second group comprised 28 varieties released from 1991 to 2004 and in the third group contained 38 modern genotypes developed from 2005 to 2012. The shifts in genetic diversity throughout the breeding periods could also be observed by PCoA, which showed broader genetic diversity of the genotypes that contributed to the second and the third periods in comparison to those that represented the first breeding period. The first group of genotypes released from 1970s to 1990 displayed significantly narrower molecular variability and was separated by the first coordinate from the other groups. The genotypes from the third breeding period were more distant from the barley genotypes from the first period, and the varieties from this breeding period were the most dispersed on the PCoA biplot and markedly overlapped with the second breeding period clusters.

The level of molecular diversity was compared between the groups of barley genotypes based on the historical breeding periods, the row type, and growth habit (Table 2). The highest number of alleles per locus (5.80), private alleles (1.4), unbiased expected heterozygosity (0.66), PIC value (0.65), and total number of detected alleles (290) were detected in the genotypes released in the last breeding period (2005-2012). This barley group was characterized by the highest values of all molecular diversity parameters, except for the allele richness. The varieties from the second breeding period (1991-2004) demonstrated less molecular diversity, whereas the barley varieties developed during the first breeding period (1973-1990) proved to be the least diverse. 


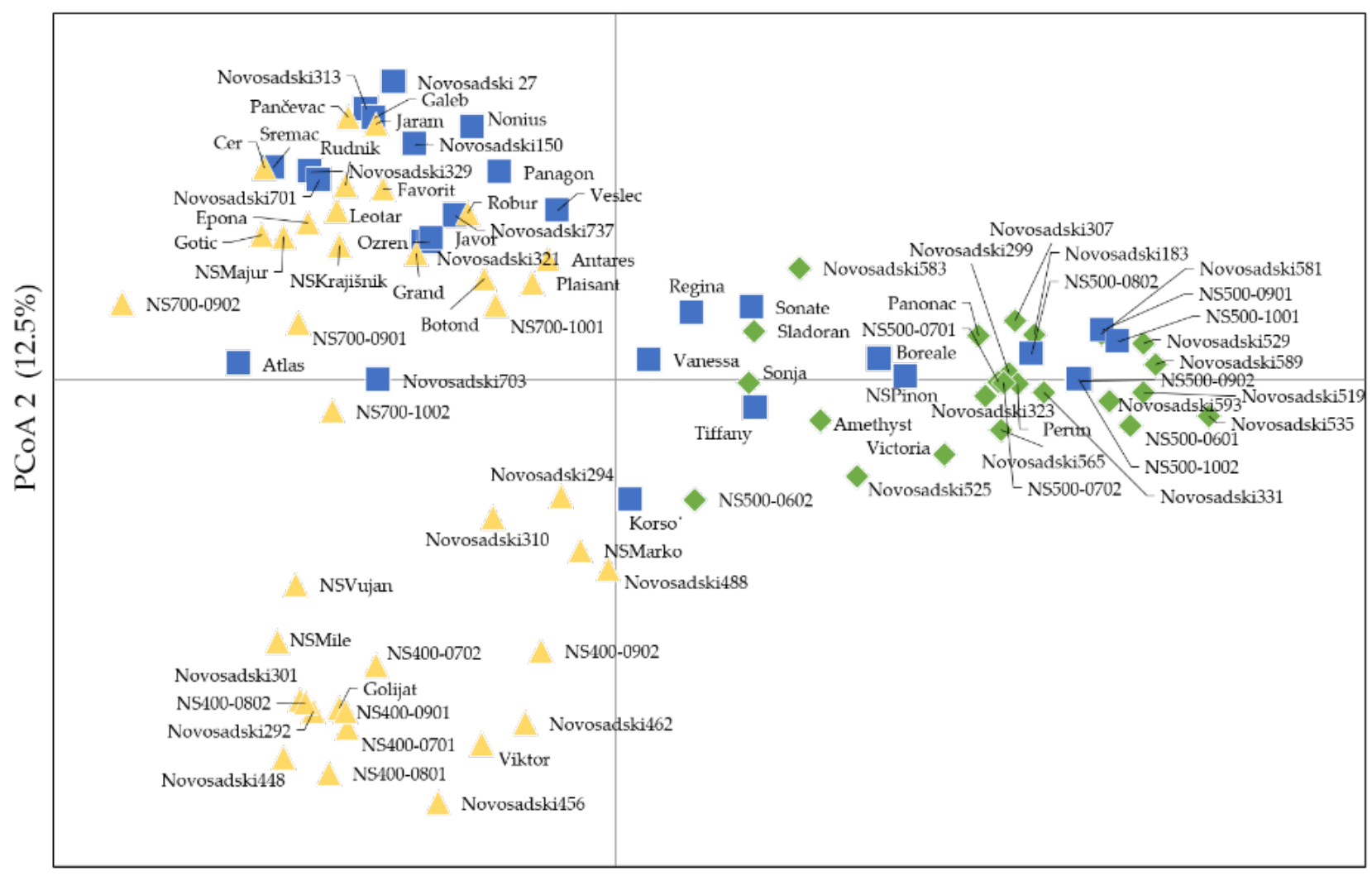

PCoA $1(22.4 \%)$

Figure 3. Principal coordinate analysis of 90 barley genotypes based on microsatellite data and the year of release. The historical period of release: green diamond-group I of varieties released from 1973 to 1990; blue square-group II of varieties released from 1991 to 2004; yellow triangle-group III of varieties released from 2005 to 2012.

Table 2. Molecular diversity parameters in barley groups according to the breeding period, growth habit, and row type.

\begin{tabular}{ccccccccc}
\hline & Na & I & Np & Ne & uHe & PIC & TNa & AR \\
\hline Breeding period \\
1977-1990 (I group) & 3.72 & 0.82 & 0.28 & 2.19 & 0.43 & 0.43 & 186 & 7.75 \\
1991-2004 (II group) & 4.46 & 1.07 & 0.48 & 2.77 & 0.56 & 0.55 & 223 & 7.96 \\
2005-2012 (III group) & 5.80 & 1.35 & 1.40 & 3.58 & 0.66 & 0.65 & 290 & 7.63 \\
& \multicolumn{7}{c}{ Growth habit and row type } \\
W2R ${ }^{1}$ & 4.80 & 1.05 & 0.70 & 2.62 & 0.53 & 0.53 & 240 & 6.67 \\
W6R & 4.48 & 0.95 & 0.54 & 2.43 & 0.48 & 0.47 & 224 & 6.40 \\
S2R & 4.84 & 1.24 & 0.86 & 3.34 & 0.64 & 0.62 & 242 & 12.74 \\
\hline
\end{tabular}

${ }^{1}$ W2R-winter two-rowed type, W6R-winter six-rowed type, S2R-spring two-rowed type, Na-number of detected alleles per locus, I-Shannon's information index, $\mathrm{Np}-$ number of private alleles, $\mathrm{Ne}-$ number of effective alleles, $\mathrm{He}$ - unbiased expected heterozygosity, PIC—-polymorphism information content, TNa—total number of alleles, AR-allelic richness.

Considering the grouping based on spike architecture and seasonal growth habit, the spring two-rowed barley manifested the highest values for all molecular diversity parameters, although this group comprised the smallest number of genotypes (Table 2). The winter two-rowed varieties were more diverse than winter six-rowed types, taking into account all diversity parameters.

The AMOVA analysis showed that $37 \%$ of the total molecular variance attributed to genetic variation among populations, the main proportion of the total molecular variation $(62 \%)$ was explained by variation among individuals within the groups, while only $1 \%$ of the total variance was associated with differentiations within individuals (Table 3). Pairwise 
Nei genetic distances between groups ranged from 0.309 (between W2R and W6R) to 0.499 (W6R and S2R).

Table 3. Analysis of molecular variance among and within barley groups.

\begin{tabular}{|c|c|c|c|c|c|c|c|}
\hline Source of Variation & $\mathrm{df}^{1}$ & MS & Est. Var. & Var & Nei & PhiPT & $p$ Value \\
\hline Among groups & 2 & 407.5 & 6.65 & $37 \%$ & $\begin{array}{c}0.309 \text { (W2R vs. W6R) } \\
0.472 \text { (W2R vs. S2R) } \\
0.499 \text { (W6R vs. S2R) }\end{array}$ & 0.375 & 0.001 \\
\hline Among individuals & 87 & 22.01 & 10.94 & $62 \%$ & & & \\
\hline Within individuals & 90 & 0.12 & 0.12 & $1 \%$ & & & \\
\hline Total & 179 & & 17.71 & & & & \\
\hline
\end{tabular}

${ }^{1} \mathrm{df}$-degrees of freedom; MS—mean square; Est. var-estimated variance; Var—-the percentage of total molecular variance attributed to variance among populations, among individuals and within individuals; Nei-pairwise population Nei's genetic distance, PhiPTpopulation differentiation value, W2R-winter two-rowed type, W6R-winter six-rowed type, S2R-spring two-rowed type.

In order to examine the correlation between molecular and pedigrees data, the genetic distances matrices based on the microsatellite and pedigree data were compared. The comparison of SSR and pedigree distance matrices using Mantel test showed a significant and a moderately low positive correlation $(r=0.53, p<0.001)$ (Figure 4a). In addition, the correlation between the molecular and phenotypic data (Figure $4 \mathrm{~b}$ ) were also positive and slightly higher $(r=0.66, p<0.001)$ than the correlation between molecular and pedigrees data.

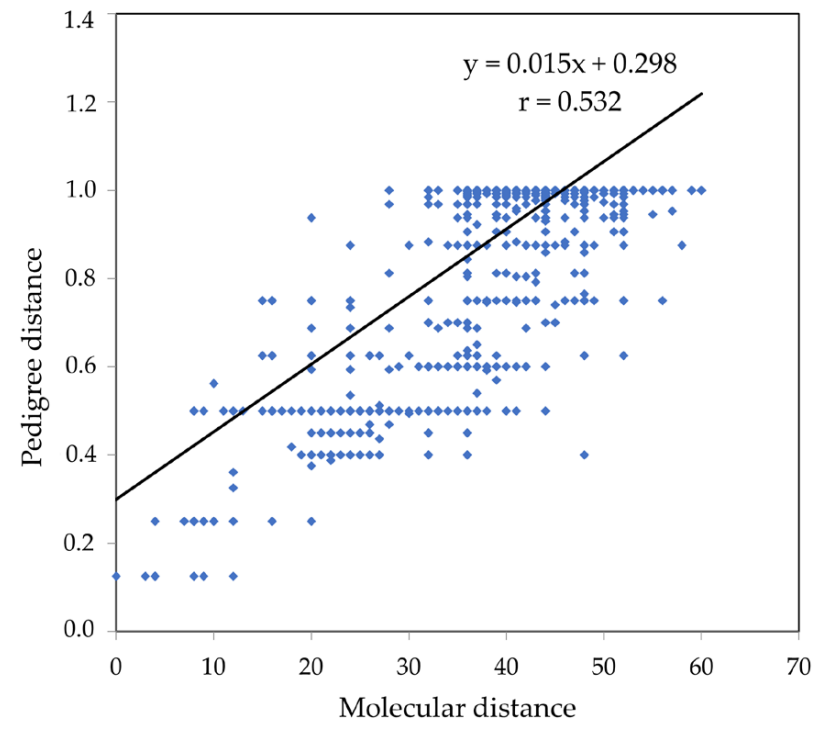

(a)

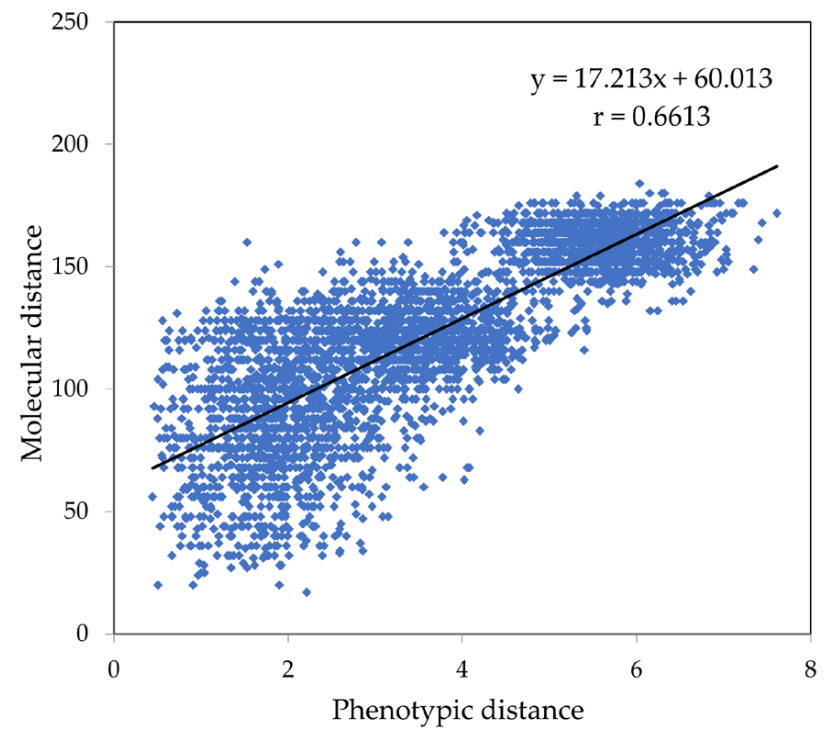

(b)

Figure 4. Correlations between molecular and pedigree similarity matrices (a) and between phenotypic and molecular similarity matrices (b) by Mantel test in GeneAlex 6.5 program.

In order to test if the combination of the independent variables simultaneously explained a significant amount of variance in the dependent variables, MANOVA was performed (Table S3). The multivariate Wilk's lambda test showed significant main effects of the season, row type, breeding period, and their interactions. Partial eta-square values were used to indicate the proportion of the variation in the dependent variables associated with the main effects and their interaction. The results showed that $50.7 \%$ and $83.7 \%$ of the variance is accounted for by the season and the row type, respectively, while the breeding period and the interactions accounted for much less.

The ANOVA for each trait separately showed that most of the investigated traits varied significantly between seasons, row types, and breeding periods (Table 4, Tables S4-S11). 
The effect of the season was not significant for hectoliter weight, whereas the effect of breeding period was not significant for spike length and hectoliter weight. In addition to individual main effects, the mutual interactions for most of the analyzed traits were also significant (Table 4, Tables S4-S11). The season by breeding period interaction was not significant only for spike length. The interactions between row types were not significant for plant height, spike length, and thousand grain weight. The significant season by row type by breeding period interactions were determined for all traits but spike length and thousand grain weight. For all traits, the partial eta-square values were the highest for the row type, followed by the season (Tables S4-S11).

Table 4. Comparison of means for eight agronomical traits of two-rowed winter, two-rowed spring, and six-rowed varieties for different breeding periods and summary ANOVA.

\begin{tabular}{|c|c|c|c|c|c|c|c|c|c|}
\hline $\begin{array}{c}\text { Groups } \\
\text { (No of } \\
\text { Genotypes) }\end{array}$ & Breeding Periods & $\begin{array}{c}\text { HT }^{1} \\
\text { (Days) }\end{array}$ & $\begin{array}{c}\text { FT } \\
\text { (Days) }\end{array}$ & PH (cm) & SL (cm) & GN & $\begin{array}{c}\text { TGW } \\
\text { (g) }\end{array}$ & HW (g) & $\begin{array}{l}\text { YLD } \\
\left.\text { (tha }{ }^{-1}\right)\end{array}$ \\
\hline \multirow[t]{5}{*}{ W2R (36) } & I & $203 b$ & $206 b$ & $89.4 b$ & $9.3 \mathrm{a}$ & \multirow{3}{*}{$\begin{array}{c}17,352 \mathrm{a} \\
18,009 \\
a b \\
18,390 \mathrm{~b}\end{array}$} & $42.0 \mathrm{a}$ & $72.4 \mathrm{a}$ & $7.09 \mathrm{a}$ \\
\hline & II & $201 \mathrm{a}$ & 204 a & 85.6 a & $10.2 \mathrm{~b}$ & & $44.4 \mathrm{~b}$ & $72.5 \mathrm{a}$ & $7.86 \mathrm{~b}$ \\
\hline & III & $201 \mathrm{a}$ & 204 a & $85.0 \mathrm{a}$ & $10.3 \mathrm{~b}$ & & $45.1 \mathrm{~b}$ & $74.1 \mathrm{~b}$ & $8.06 \mathrm{~b}$ \\
\hline & $\mathrm{CV}(\%)$ & 2.8 & 2.9 & 12.8 & 13.5 & 19.3 & 11.2 & 3.3 & 21.9 \\
\hline & Average & 202 & 205 & 86.5 & 10.0 & 17,870 & 43.8 & 72.9 & 7.70 \\
\hline \multirow[t]{5}{*}{ S2R (19) } & I & $72 \mathrm{a}$ & $74 \mathrm{a}$ & $70.3 \mathrm{ab}$ & $8.7 \mathrm{a}$ & $11,961 \mathrm{a}$ & $31.9 \mathrm{a}$ & $66.8 \mathrm{a}$ & $4.14 \mathrm{a}$ \\
\hline & II & $73 \mathrm{a}$ & 75 a & $68.7 \mathrm{a}$ & $9.4 \mathrm{ab}$ & $12,047 \mathrm{a}$ & $36.2 \mathrm{~b}$ & $67.8 \mathrm{a}$ & $4.31 \mathrm{a}$ \\
\hline & III & $72 \mathrm{a}$ & $74 \mathrm{a}$ & $72.4 \mathrm{~b}$ & $9.6 \mathrm{~b}$ & $13,377 \mathrm{a}$ & $37.0 \mathrm{~b}$ & $69.2 \mathrm{~b}$ & $4.46 \mathrm{a}$ \\
\hline & $\mathrm{CV}(\%)$ & 2.0 & 1.9 & 13.0 & 12.6 & 20.3 & 14.8 & 5.5 & 21.9 \\
\hline & Average & 72 & 74 & 71.2 & 9.4 & 12,309 & 35.7 & 68.4 & 4.36 \\
\hline \multirow[t]{12}{*}{ W6R (35) } & I & $209 c$ & $211 \mathrm{c}$ & $92.0 \mathrm{~b}$ & $6.5 \mathrm{a}$ & 18,787 a & $34.9 \mathrm{a}$ & $68.0 \mathrm{a}$ & $6.70 \mathrm{a}$ \\
\hline & II & $206 \mathrm{~b}$ & $209 \mathrm{~b}$ & $87.1 \mathrm{a}$ & $6.7 \mathrm{a}$ & $19,000 \mathrm{a}$ & $38.6 \mathrm{~b}$ & $68.2 \mathrm{a}$ & $7.25 b$ \\
\hline & III & 204 a & 207 a & $87.5 \mathrm{a}$ & $6.9 \mathrm{a}$ & $20,067 \mathrm{~b}$ & $39.2 \mathrm{~b}$ & $68.7 \mathrm{a}$ & $7.66 \mathrm{c}$ \\
\hline & $\mathrm{CV}(\%)$ & 7.0 & 7.1 & 8.7 & 27.9 & 28.9 & 13.2 & 4.9 & 26.4 \\
\hline & Average & 206 & 209 & 88.8 & 6.7 & 19,330 & 37.6 & 68.3 & 7.23 \\
\hline & Season & $* * *$ & $* * *$ & $* * *$ & $* *$ & $* * *$ & $* * *$ & ns & $* * *$ \\
\hline & Row type & $* * *$ & $* * *$ & $* * *$ & $* * *$ & $* * *$ & $* * *$ & $* * *$ & $* * *$ \\
\hline & Breeding period & $* * *$ & $* * *$ & $* *$ & ns & $* *$ & $* * *$ & ns & $* * *$ \\
\hline & Season $\times$ row type & $* * *$ & $* * *$ & * & * & $* * *$ & ** & $* *$ & $* * *$ \\
\hline & $\begin{array}{l}\text { Season } \times \text { breeding } \\
\text { period }\end{array}$ & $* * *$ & $* * *$ & $* * *$ & ns & $* * *$ & $* * *$ & * & $* * *$ \\
\hline & $\begin{array}{c}\text { Row type } \times \\
\text { breeding period }\end{array}$ & $*$ & * & ns & ns & $* * *$ & ns & $* *$ & * \\
\hline & $\begin{array}{l}\text { Season } \times \text { row type } \\
\times \text { breeding period }\end{array}$ & $* * *$ & $* * *$ & * & ns & $* * *$ & ns & $* *$ & * \\
\hline
\end{tabular}

${ }^{1} \mathrm{HD}$-heading date, FT—flowering time, SH—stem height, SL—spike length, HW-hectoliter weight, TGW—thousand grain weight, YLD—yield, GN—grain number per $1 \mathrm{~m}^{2}$; W2R—winter two-rowed type, S2R—spring two-rowed type, W6R—winter six-rowed type; I, II, III—breeding periods. CV—coefficient of variation. Different letters indicate significant differences $(p<0.05)$ between mean values obtained by Tukey's multiple comparison test. ${ }^{* * *}$ significance at 0.001 probability level, ** significance at 0.01 probability level, ** significance at 0.05 probability level, ns-non significant.

Comparison of three groups with different row types revealed that two-rowed winter barley had earlier heading and flowering time than six-rowed types. Furthermore, the tworowed winter group showed shorter stems, longer spikes, less grain number per $\mathrm{m}^{2}$, greater thousand grain weight, greater hectoliter weight, and greater yield than the six-rowed types. Most of the yield-related traits had the lowest values for the spring two-rowed barley group. Yield and grain number per $\mathrm{m}^{2}$ had the highest coefficients of variation ranging from $21.9 \%$ to $26.4 \%$ and from $19.3 \%$ to $28.9 \%$, respectively. The smallest variation was observed for the heading and flowering time with coefficients of variation varying from $2.8 \%$ to $7 \%$ and from $2.9 \%$ to $7.1 \%$, respectively (Table 4 ). 
The varieties that belonged to different historical breeding periods significantly differed with respect to almost all of the investigated traits. The earliest heading and flowering time were observed in the third historical period for the six-rowed barley varieties, and in the second and third period for the two-rowed winter barley group. The average value of plant height significantly decreased in the last two breeding periods compared to the first period in the two- and six-rowed winter varieties. The significant increase of spike length during the breeding periods was noticed in two-rowed winter and spring barley, while the changes for the six-rowed barley over time was not detected. Both two- and six-rowed winter varieties showed an increase in grain numbers per $\mathrm{m}^{2}$ over time. Thousand grain weight significantly increased throughout the investigated historical periods, especially in the two last for all three barley groups. For both winter and spring two-rowed varieties, there was a significant increase in hectoliter weight in the third period. No significant changes of hectoliter weight over 40 years were observed for the six-rowed type. Yield, as one of the most important agronomic traits, improved significantly over time. This trend of a graduate increase was more pronounced in six-rowed winter types, with the mean values ranging from 6.7 tha ${ }^{-1}$ over 7.25 tha $^{-1}$ to 7.66 tha $^{-1}$. The yield was also considerably improved in the second and the third period in two-rowed winter barley, with the average values of this trait increasing from 7.09 tha $^{-1}$ to 8.06 tha $^{-1}$ (Table 4).

\section{Discussion}

Globally, the breeding of modern cereals caused a rapid decrease of genetic diversity level over time due to focused selections on targeted genes or quantitative trait loci (QTLs) [42]. Therefore, the information of the current state of genetic diversity and the level of a potential genetic reduction in European germplasm could be of great importance for barley breeding in effectively improving important traits and accurately estimating genetic relationships and diversity [43]. Gougerdchi et al. [8] emphasized the assessment of genetic diversity based on molecular markers as one of the primary and essential steps in the modern breeding strategy. Considering the significance of revealing allelic changes and population structure over time [44,45], the aim of our study was to detect changes that occurred during several decades of breeding efforts at IFVCNS. The molecular diversity parameters implied a considerable variability in our barley collection. Among 90 analyzed barley genotypes, the chosen set of 50 markers amplified 6.76 alleles per locus, with a range from 1 to 16 alleles and mean PIC of 0.62 . The results were comparable with the findings of Varshney et al. [46], who reported an average PIC value of 0.58 in barley lines from six countries using 28 microsatellites. Our results also agreed with the mean PIC value of 0.57 in Brazilian genotypes obtained with 34 SSR loci [10]. In other diversity studies, mean PIC values were somewhat lower than those presented in this study, ranging from 0.28 to $0.46[8,47,48]$, which could probably be due to a relatively small area of the genotypes' origin [5]. Rajala et al. [9], however, demonstrated a satisfactory level of variability in northern European barley genotypes, hence contesting the effect of genetic erosion implicated by geographical frontiers and complying with a high level of genetic diversity found in our barley collection.

The introduction of new breeding material had great importance for improving the most important selection traits. In this study, two-rowed spring and winter varieties had higher values of genetic diversity parameters than the six-rowed varieties, which is in agreement with the findings of Surlan-Momirovic et al. [49] and could be explained with the use of more diverse breeding material for developing two-rowed varieties and more intensive germplasm exchange of two-rowed barley than that of the analyzed six-rowed barley. Therefore, the introduction of novel germplasm and a more comprehensive usage of genetic resources led to the enlargement of variability with new alleles in the Serbian breeding program, which was especially evident in the second and third breeding periods.

Genetic relatedness among the barley varieties was estimated using Bayesian clustering, PCoA, and analysis of molecular variance. The results of both methods outlined by Pritchard et al. [35] and by Evanno et al. [36], as well as biological factors that could 
influence the choice of $\mathrm{K}$ [50], were considered when selecting the appropriate number of clusters (in our case $\mathrm{K}=3$ ). To avoid underestimating population structure using only one method to only two clusters as the top level of hierarchical structure and to ensure reproducibility of structure results, we performed a hierarchical analysis, including structure bar plots for multiple values of $\mathrm{K}$ according to the Janes et al. [51]. In our study, although the maximum value of $\operatorname{Ln}(\operatorname{Pr}(X \mid K)$ was reached for nine clusters, this result did not have its full biological and agronomical justification. On the other hand, the results based on Evanno method in our case did not underestimate the number of groups and the obtained three clusters best defined the studied barley collection according to growth habit and row type. The division of the genotypes into more groups was not clear and could be only partially explained by different breeding periods, row types, and the counties of origin. Many studies of the worldwide [52], European [53], American [54], and Nordic [9,55] barley germplasm confirmed that population structure was largely conditioned by differences in row type. Moreover, Mathies et al. [56] in a genome wide association study of malting and kernel quality showed that grouping of European barley according to seasonal growth habit and row number could be achieved more preciously and accurately with fewer SSR markers than with more Diversity arrays technology (DArT) markers, which was also confirmed in the studies that compared SSRs with other types of markers $[57,58]$.

The AMOVA results supported the PCoA and structure analysis. The partitioning of molecular variation showed that highest variation was determined among individuals within the same group, implicating differentiation of both seasonal growth habit and ear row type. Similarly, Khodayari et al. [16] reported the highest diversity (60.7\%) among Iranian accessions detected within the same row type, while Koebner et al. [44] noted a significant part of molecular variance attributed to the seasonal group. Malysheva et al. [45] accounted for $17 \%$ and $19.5 \%$ of variation between spring and winter, and between tworowed and six-rowed varieties, respectively, which was similar to the variance share observed between the groups in our study.

The presence of moderately low correlation $(r=0.53)$ between microsatellites and pedigree data was comparative to the correlation $(\mathrm{r}=0.46)$ between the pedigree data of 92 Canadian barley varieties and 50 SSR markers [19]. The relatively low correlation between microsatellites and pedigree data could be a consequence of pedigree errors which are common in breeding. Moreover, inaccurate pedigrees could also be due to incomplete data, as a lack of some ancestry information could prevent pedigrees from being traced back for several generations. Since breeding is a complex multistep process, the presence of incorrect pedigrees could subsequently lead to inadequate estimates of genetic parameters such as additive variance, heritability, genetic correlations, and breeding value [21]. This deficiency in pedigree data could be corrected by simultaneous genotyping parents and progeny applying dense panel of molecular markers [59]. A stronger correlation could be obtained with more markers that would allow more precise estimation of actual relationships between related genotypes and identification of the genome regions that were inherited from a common ancestor [60]. A slightly higher correlation was determined between molecular and phenotypic data $(\mathrm{r}=0.66)$. This was considerably lower than the correlation $(0.82)$ found between similarity distances of 21 microsatellites and 21 morphological traits in the study of Koebner et al. [44]. It is possible that the agronomic traits used in our study had less discriminative power, which was, in turn, reflected in a lower correction. A positive effect on observed yield progress during the 40-year long breeding period could be partly attributed to breeding for shorter plants, which reduced lodging and thus provided higher yield stability. This is in agreement with Ortiz et al. [61], who observed a reduction of stem height in Nordic spring barley varieties by $0.20 \mathrm{~cm}$ per year from 1948 to 1988. The observed effect of the season on plant height is in accordance with $[3,62]$ who demonstrated a large influence of environmental factors on the expression of stem height. The shift from later heading and flowering varieties from the first and the second breeding periods towards earlier heading and flowering genotypes from the third period could be interpreted as a strategy to avoid drought [63], which is in the Pannonian Basin and other 
European countries one of the main limiting factors for agriculture production [64]. The increase in thousand grain weight of both two- and six-rowed types during the breeding periods was in accordance with the findings of Schwarz et al. [65] who detected consistent, although not significant, improvement of thousand grain weight from 1910 to 1990 . Both two- and six-rowed varieties developed during the most recent period showed improved yield-related traits, such as thousand kernel weight and grain numbers per plot, reflecting an enlargement of genotypic diversity, which was also confirmed by the molecular analysis.

The selected microsatellites revealed a considerable level of genetic diversity, proving suitable for the characterization of barley germplasm and its more efficient use in barley selection process. Unlike the barley breeding in some countries that underwent a decline in genetic diversity $[3,66]$, molecular and phenotypic analyses in our study indicated no genetic erosion in barley genotypes from central and southeast Europe used over the last several decades. A considerable molecular and phenotypic diversity of the analyzed barley varieties implied their great potential for further barley improvement and quantitative trait studies.

\section{Conclusions}

The introduction of novel germplasm and more comprehensive use of genetic resources could be of great importance in increasing the variability with new alleles in Serbian breeding program, which was especially evident in the second and the third breeding periods. The relatively low correlation between microsatellites and pedigree data could be a consequence of unavailable pedigree or pedigree errors, which are common in most breeding programs. Yield progress during the 40-year long breeding tradition could be partly attributed to breeding for shorter plants, which reduced lodging and thus provided higher yield adaptability and stability. The selection of earlier heading and flowering genotypes from the third period could be interpreted as a strategy to avoid drought as one of the main limiting factors for agriculture production in the Pannonian Basin and other European countries.

Supplementary Materials: The following are available online at https://www.mdpi.com/2073 $-4395 / 11 / 1 / 118 / s 1$, Figure S1: Estimation of the number of subpopulations $(\Delta \mathrm{K})$ calculated by Evanno' s approach (2005) obtained in program Structure harvester and Clumpak program. Figure S2: Probability of data (Ln) for number of clusters (K) ranging from 2 to 10 obtained by Structure harvester and Clumpak program. Table S1: The name of markers, their forward and backward primer sequences, annealing temperatures, and repeat motifs. Table S2: The name of markers, their position on the chromosome, size range of detected alleles, and basic molecular diversity parameters. Table S3: Multivariate analysis of variance (MANOVA) using Wilks' Lambda test differences between group means for a combination of the analyzed agronomical traits. Table S4: Analysis of variance for heading time with partial eta-square. Table S5: Analysis of variance for flowering time with partial eta-square. Table S6: Analysis of variance for plant height with partial eta-square. Table S7: Analysis of variance for spike length with partial eta-square. Table S8: Analysis of variance for grain number per square meter with partial eta-square. Table S9: Analysis of variance for thousand grain weight with partial eta-square. Table S10: Analysis of variance for hectoliter weight with partial eta-square. Table S11: Analysis of variance for yield with partial eta-square.

Author Contributions: Conceptualization, M.M. and L.B.; methodology, M.M. and V.A.; software, S.M.; validation, D.T., V.A., and V.M.; formal analysis, L.B., S.M., and V.M.; investigation, M.M. and D.T.; resources, S.M. and L.P.; data curation, D.T.; writing—original draft preparation, L.B. and S.M.; writing-review and editing, all authors; visualization, L.B. and V.A.; supervision, B.D., V.A., and L.P.; project administration, B.D.; funding acquisition, B.D. All authors have read and agreed to the published version of the manuscript.

Funding: This research received no external funding.

Institutional Review Board Statement: Not applicable.

Informed Consent Statement: Not applicable. 


\section{Data Availability Statement: Not applicable.}

Acknowledgments: This research was supported by the Ministry of Education, Science and Technological Development of the Republic of Serbia, grant number: 451-03-68/2020-14/200032.

Conflicts of Interest: The authors declare no conflict of interest.

\section{References}

1. Ingvordsen, C.H.; Backes, G.; Lyngkjær, M.F.; Peltonen-Sainio, P.; Jahoor, A.; Mikkelsen, T.N.; Jørgensen, R.B. Genome-Wide Association Study of Production and Stability Traits in Barley Cultivated under Future Climate Scenarios. Mol. Breed. 2015, 35, 84. [CrossRef]

2. Laidò, G.; Mangini, G.; Taranto, F.; Gadaleta, A.; Blanco, A.; Cattivelli, L.; Marone, D.; Mastrangelo, A.M.; Papa, R.; De Vita, P. Genetic Diversity and Population Structure of Tetraploid Wheats (Triticum turgidum L.) Estimated by SSR, DArT and Pedigree Data. PLoS ONE 2013, 8, e67280. [CrossRef]

3. Kolodinska Brantestam, A.; Von Bothmer, R.; Dayteg, C.; Rashal, I.; Tuvesson, S.; Weibull, J. Genetic Diversity Changes and Relationships in Spring Barley (Hordeum vulgare L.) Germplasm of Nordic and Baltic Areas as Shown by SSR Markers. Genet. Resour. Crop Evol. 2007, 54, 749-758. [CrossRef]

4. Mir, R.R.; Kumar, J.; Balyan, H.S.; Gupta, P.K. A Study of Genetic Diversity among Indian Bread Wheat (Triticum aestivum L.) Cultivars Released during Last 100 Years. Genet. Resour. Crop Evol. 2012, 59, 717-726. [CrossRef]

5. Hamza, S.; Wafa, B.; Rebai, A.; Harrabi, M. SSR-Based Genetic Diversity Assessment among Tunisian Winter Barley and Relationship with Morphological Traits. Euphytica 2004, 135, 107-118. [CrossRef]

6. Elakhdar, A.; Kumamaru, T.; Qualset, C.O.; Brueggeman, R.S.; Amer, K.; Capo-chichi, L. Assessment of genetic diversity in Egyptian barley (Hordeum vulgare L.) genotypes using SSR and SNP markers. Genet. Resour. Crop Evol. 2018, 65, 1937-1951. [CrossRef]

7. Yahiaoui, S.; Igartua, E.; Moralejo, M.; Ramsay, L.; Molina-Cano, J.L.; Ciudad, F.J.; Lasa, J.M.; Gracia, M.P.; Casas, A.M. Patterns of Genetic and Eco-Geographical Diversity in Spanish Barleys. Theor. Appl. Genet. 2008, 116, 271-282. [CrossRef]

8. Gougerdchi, V.; Dezhsetan, S.; Ebrahimi, M.A.; Sadeghzadeh, B.; Savari, S. Using SSR Markers for Assessment Genetic Diversity And Detection Drought Escape Candidate Genes In Barley Lines (Hordeum vulgare L.). Plant Breed. Seed Sci. 2018, 70, 3-14. [CrossRef]

9. Rajala, A.; Peltonen-Sainio, P.; Jalli, M.; Jauhiainen, L.; Hannukkala, A.; Tenhola-Roininen, T.; Ramsay, L.; Manninen, O. One Century of Nordic Barley Breeding: Nitrogen Use Efficiency, Agronomic Traits and Genetic Diversity. J. Agric. Sci. 2017, 155, 582-598. [CrossRef]

10. Ferreira, J.R.; Pereira, J.F.; Turchetto, C.; Minella, E.; Consoli, L.; Delatorre, C.A. Assessment of Genetic Diversity in Brazilian Barley Using SSR Markers. Genet. Mol. Biol. 2016, 39, 86-96. [CrossRef]

11. Russell, J.; Booth, A.; Fuller, J.; Harrower, B.; Hedley, P.; Machray, G.; Powell, W. A Comparison of Sequence-Based Polymorphism and Haplotype Content in Transcribed and Anonymous Regions of the Barley Genome. Genome 2004, 47, 389-398. [CrossRef] [PubMed]

12. Ledovskoy, Y.; Abugalieva, S.; Turuspekov, Y. Comparative Assessment of the Genetic Variation in Wild and Cultivated Barley Based on SSR Markers. Asian Australas. J. Plant Sci. Biotechnol. 2010, 4, 21-26.

13. Nandha, P.S.; Singh, J. Comparative Assessment of Genetic Diversity between Wild and Cultivated Barley Using GSSR and EST-SSR Markers. Plant Breed. 2014, 133, 28-35. [CrossRef]

14. Flint-Garcia, S.A.; Thornsberry, J.M.; Buckler, E.S. Structure of Linkage Disequilibrium in Plants. Annu. Rev. Plant Biol. 2003, 54, 357-374. [CrossRef] [PubMed]

15. Baik, B.K.; Ullrich, S.E. Barley for Food: Characteristics, Improvement, and Renewed Interest. J. Cereal Sci. 2008, 48, 233-242. [CrossRef]

16. Khodayari, H.; Saeidi, H.; Roofigar, A.A.; Rahiminejad, M.R.; Pourkheirandish, M.; Komatsuda, T. Genetic Diversity of Cultivated Barley Landraces in Iran Measured Using Microsatellites. Int. J. Biosci. Biochem. Bioinf. 2012, 2, 287-290. [CrossRef]

17. Newton, A.C.; Flavell, A.J.; George, T.S.; Leat, P.; Mullholland, B.; Ramsay, L.; Revoredo-Giha, C.; Russell, J.; Steffenson, B.J.; Swanston, J.S.; et al. Crops That Feed the World 4. Barley: A Resilient Crop? Strengths and Weaknesses in the Context of Food Security. Food Secur. 2011, 3, 141. [CrossRef]

18. Zhou, G.; Zhang, Q.; Zhang, X.Q.; Tan, C.; Li, C. Construction of High-Density Genetic Map in Barley through Restriction-Site Associated DNA Sequencing. PLoS ONE 2015, 10, e0133161. [CrossRef]

19. Lamara, M.; Zhang, L.Y.; Marchand, S.; Tinker, N.A.; Belzile, F. Comparative Analysis of Genetic Diversity in Canadian Barley Assessed by SSR, DarT, and Pedigree Data. Genome 2013, 56, 351-358. [CrossRef]

20. Komatsuda, T.; Pourkheirandish, M.; He, C.; Azhaguvel, P.; Kanamori, K.; Perovic, D.; Stein, N.; Graner, A.; Wicker, T.; Tagiri, A.; et al. Six-Rowed Barley Originated from a Mutation in a Homeodomain-Leucine Zipper I-Class Homeobox Gene. Proc. Natl. Acad. Sci. USA 2007, 104, 1424-1429. [CrossRef]

21. Muñoz-Amatriaín, M.; Cuesta-Marcos, A.; Endelman, J.B.; Comadran, J.; Bonman, J.M.; Bockelman, H.E.; Chao, S.; Russell, J.; Waugh, R.; Hayes, P.M.; et al. The USDA Barley Core Collection: Genetic Diversity, Population Structure, and Potential for Genome-Wide Association Studies. PLoS ONE 2014, 9, e94688. [CrossRef] 
22. Grover, A.; Sharma, P.C. Development and Use of Molecular Markers: Past and Present. Crit. Rev. Biotechnol. 2016, 36, 290-302. [CrossRef] [PubMed]

23. Friedt, W.; Horsley, R.D.; Harvey, B.L.; Poulsen, D.M.E.; Lance, R.C.M.; Ceccarelli, S.; Grando, S.; Capettini, F. Barley Breeding History, Progress, Objectives, and Technology; Ullrich, S.E., Ed.; Wiley-Blackwell: Hoboken, NJ, USA, 2010; pp. $160-222$.

24. Mikić, S.; Kondić-Špika, A.; Brbaklić, L.; Stanisavljević, D.; Ćeran, M.; Trkulja, D.; Mitrović, B. Molecular and Phenotypic Characterisation of Diverse Temperate Maize Inbred Lines in Southeast Europe. Zemdirbyste 2017, 104, 31-40. [CrossRef]

25. Hwang, T.Y.; Gwak, B.S.; Sung, J.; Kim, H.S. Genetic diversity patterns and discrimination of 172 korean soybean (Glycine max (L.) merrill) varieties based on SSR analysis. Agriculture 2020, 10, 77. [CrossRef]

26. Vieira, M.L.C.; Santini, L.; Diniz, A.L.; Munhoz, C.d.F. Microsatellite Markers: What They Mean and Why They Are so Useful. Genet. Mol. Biol. 2016, 39, 312-328. [CrossRef]

27. Liu, Y.; Ge, Y.; Zhan, R.; Lin, X.; Zang, X.; Li, Y.; Yang, Y.; Ma, W. Molecular markers and a quality trait evaluation for assessing the genetic diversity of avocado landraces from china. Agriculture 2020, 10, 102. [CrossRef]

28. Feng, Z.; Zhang, Y.; Ling, H. Microsatellite Markers and Applications in the Barley Genome. Yi Chuan Hered. $2002,24,727-733$.

29. Karakousis, A.; Barr, A.R.; Chalmers, K.J.; Ablett, G.A.; Holton, T.A.; Henry, R.J.; Lim, P.; Langridge, P. Potential of SSR Markers for Plant Breeding and Variety Identification in Australian Barley Germplasm. Aust. J. Agric. Res. 2003, 54, 1197-1210. [CrossRef]

30. Kandemir, N.; Ahmet, Y.; Rahime, G. Determining the Levels of Genetic Variation Using SSR Markers in Three Turkish Barley Materials Known as Tokak. Turk. J. Agric. For. 2010, 34, 17-23. [CrossRef]

31. Mirosavljević, M.; Momčilović, V.; Pržulj, N.; Hristov, N.; Aćin, V.; Čanak, P.; Denčić, S. The Variation of Agronomic Traits Associated with Breeding Progress in Winter Barley Cultivars. Zemdirb.-Agric. 2016, 103, 267-272. [CrossRef]

32. Doyle, J.J.; Doyle, J.L. Isolation of plant DNA from fresh tissue. Focus 1990, 12, 39-40.

33. Röder, M.S.; Korzun, V.; Wendehake, K.; Plaschke, J.; Tixier, M.H.; Leroy, P.; Ganal, M.W. A microsatellite map of wheat. Genetics 1998, 149, 2007-2023. [PubMed]

34. Peakall, R.; Smouse, P.E. GenALEx 6.5: Genetic Analysis in Excel. Population Genetic Software for Teaching and Research-an Update. Bioinformatics 2012, 28, 2537-2539. [CrossRef] [PubMed]

35. Pritchard, J.K.; Stephens, M.; Donnelly, P. Inference of Population Structure Using Multilocus Genotype Data. Genetics 2000, $155,945-959$.

36. Evanno, G.; Regnaut, S.; Goudet, J. Detecting the Number of Clusters of Individuals Using the Software STRUCTURE: A Simulation Study. Mol. Ecol. 2005, 14, 2611-2620. [CrossRef]

37. Earl, D.A.; von Holdt, B.M. STRUCTURE HARVESTER: A Website and Program for Visualizing STRUCTURE Output and Implementing the Evanno Method. Conserv. Genet. Resour. 2012, 4, 359-361. [CrossRef]

38. Kopelman, N.M.; Mayzel, J.; Jakobsson, M.; Rosenberg, N.A.; Mayrose, I. CLUMPAK: A program for identifying clustering modes and packaging population structure inferences across K. Mol. Ecol. Resour. 2015, 15, 1179-1191. [CrossRef]

39. Tinker, N.A.; Mather, D.E. KIN: Software for Computing Kinship Coefficients. J. Hered. 1993, 84, 238. [CrossRef]

40. R Core Team. R: A Language and Environment for Statistical Computing; R Foundation for Statistical Computing: Vienna, Austria, 2020; Available online: https:/ / www.R-project.org/ (accessed on 10 October 2020).

41. Goss-Sampson, M.A. Statistical Analysis in JASP: A Guide for Students. Version 2. October 2018. Available online: https:/ / static.jasp-stats.org/Statistical\%20Analysis\%20in\%20JASP\%20v0.9.2\%20-\%20A\%20Students\%20Guide.pdf (accessed on 8 October 2020).

42. Nevo, E. Evolution of Wild Wheat and Barley and Crop Improvement: Studies at the Institute of Evolution. Isr. J. Plant Sci. Isr. J. Plant Sci. 2007, 55, 251-262. [CrossRef]

43. Meszaros, K.; Karsai, I.; Kuti, C.; Banyai, J.; Lang, L.; Bedo, Z. Efficiency of Different Marker Systems for Genotype Fingerprinting and for Genetic Diversity Studies in Barley (Hordeum vulgare L.). S. Afr. J. Bot. 2007, 73, 43-48. [CrossRef]

44. Koebner, R.M.D.; Donini, P.; Reeves, J.C.; Cooke, R.J.; Law, J.R. Temporal Flux in the Morphological and Molecular Diversity of UK Barley. Theor. Appl. Genet. 2003, 106, 550-558. [CrossRef]

45. Malysheva-Otto, L.; Ganal, M.W.; Law, J.R.; Reeves, J.C.; Röder, M.S. Temporal Trends of Genetic Diversity in European Barley Cultivars (Hordeum vulgare L.). Mol. Breed. 2007, 20, 309-322. [CrossRef]

46. Varshney, R.K.; Salem, K.F.M.; Baum, M.; Roder, M.S.; Graner, A.; Börner, A. SSR and SNP Diversity in a Barley Germplasm Collection. Plant Genet. Resour. Charact. Util. 2008, 6, 167-174. [CrossRef]

47. Pandey, M.; Wagner, C.; Friedt, W.; Ordon, F. Genetic Relatedness and Population Differentiation of Himalayan Hulless Barley (Hordeum vulgare L.) Landraces Inferred with SSRs. Theor. Appl. Genet. 2006, 113, 715-729. [CrossRef] [PubMed]

48. Zhang, M.; Mao, W.; Zhang, G.; Wu, F. Development and Characterization of Polymorphic ESTSSR and Genomic SSR Markers for Tibetan Annual Wild Barley. PLoS ONE 2014, 9, e94881. [CrossRef]

49. Surlan-Momirovic, G.; Krämer, I.; Bratkovic, K.; Zoric, M.; Momirovic, U.; Brankovic, G.; Calic, I.; Kandic, V.; Przulj, N.; Ordon, F.; et al. Molecular Characterization of Barley (Hordeum vulgare L.) Accessions of the Serbian Genebank by SSR Fingerprinting. Genetika 2013, 45, 167-180. [CrossRef]

50. Gilbert, K.J.; Andrew, R.L.; Bock, D.G.; Franklin, M.T.; Kane, N.C.; Moore, J.S.; Moyers, B.T.; Renaut, S.; Rennison, D.J.; Veen, T.; et al. Recommendations for utilizing and reporting population genetic analyses: The reproducibility of genetic clustering using the program STRUCTURE. Mol. Ecol. 2012, 21, 4925-4930. [CrossRef] [PubMed] 
51. Janes, J.K.; Miller, J.M.; Dupuis, J.R.; Malenfant, R.M.; Gorrell, J.C.; Cullingham, C.I.; Andrew, R.L. The K= 2 conundrum. Mol. Ecol. 2017, 26, 3594-3602. [CrossRef]

52. Malysheva-Otto, L.V.; Ganal, M.W.; Röder, M.S. Analysis of Molecular Diversity, Population Structure and Linkage Disequilibrium in a Worldwide Survey of Cultivated Barley Germplasm (Hordeum vulgare L.). BMC Genet. 2006, 7, 6. [CrossRef]

53. Rostoks, N.; Ramsay, L.; MacKenzie, K.; Cardle, L.; Bhat, P.R.; Roose, M.L.; Svensson, J.T.; Stein, N.; Varshney, R.K.; Marshall, D.F.; et al. Recent History of Artificial Outcrossing Facilitates Whole-Genome Association Mapping in Elite Inbred Crop Varietes. Proc. Natl. Acad. Sci. USA 2006, 103, 18656-18661. [CrossRef]

54. Hamblin, M.T.; Close, T.J.; Bhat, P.R.; Chao, S.; Kling, J.G.; Abraham, K.J.; Blake, T.; Brooks, W.S.; Cooper, B.; Griffey, C.A.; et al. Population Structure and Linkage Disequilibrium in U.S. Barley Germplasm: Implications for Association Mapping. Crop Sci. 2010, 50, 556-566. [CrossRef]

55. Bengtsson, T.; Åhman, I.; Bengtsson, T.; Manninen, O.; Veteläinen, M.; Reitan, L.; Alsheikh, M.; Gertsson, B.; Tuvesson, S.; Jalli, M.; et al. Genetic Diversity, Population Structure and Linkage Disequilibrium in Nordic Spring Barley (Hordeum vulgare L. Subsp. vulgare). Genet. Resour. Crop Evol. 2017, 64, 2021-2033. [CrossRef]

56. Matthies, I.E.; van Hintum, T.; Weise, S.; Röder, M.S. Population Structure Revealed by Different Marker Types (SSR or DArT) Has an Impact on the Results of Genome-Wide Association Mapping in European Barley Cultivars. Mol. Breed. 2012, 30, 951-966. [CrossRef]

57. van Inghelandt, D.; Melchinger, A.E.; Lebreton, C.; Stich, B. Population Structure and Genetic Diversity in a Commercial Maize Breeding Program Assessed with SSR and SNP Markers. Theor. Appl. Genet. 2010, 120, 1289-1299. [CrossRef] [PubMed]

58. Amar, M.H.; Biswas, M.K.; Zhang, Z.; Guo, W.W. Exploitation of SSR, SRAP and CAPS-SNP Markers for Genetic Diversity of Citrus Germplasm Collection. Sci. Hortic. 2011, 128, 220-227. [CrossRef]

59. Cappa, E.P.; El-Kassaby, Y.A.; Muñoz, F.; Garcia, M.N.; Villalba, P.V.; Klápště, J.; Marcucci Poltri, S.N. Improving Accuracy of Breeding Values by Incorporating Genomic Information in Spatial-Competition Mixed Models. Mol. Breed. 2017, 37. [CrossRef]

60. Powell, J.E.; Visscher, P.M.; Goddard, M.E. Reconciling the Analysis of IBD and IBS in Complex Trait Studies. Nat. Rev. Genet. 2010, 11, 800-805. [CrossRef]

61. Ortiz, R.; Nurminiemi, M.; Madsen, S.; Rognli, O.A.; Bjørnstad, Å. Genetic Gains in Nordic Spring Barley Breeding over Sixty Years. Euphytica 2002, 126, 283-289. [CrossRef]

62. Madic, M.; Paunovic, A.; Djurovic, D.; Knezevic, D.; Tanaskovic, S. Breeding Barley (Hordeum vulgare L.) for Abiotic and Biotic Limiting Factors. In Proceedings of the Third International Scientific Symposium "Agrosym 2012", Jahorina, Bosnia and Herzegovina, 15-17 November 2012; Faculty of Agriculture, University of East Sarajevo: Istočno Sarajevo, Serbia, 2012; pp. $257-262$.

63. Shavrukov, Y.; Kurishbayev, A.; Jatayev, S.; Shvidchenko, V.; Zotova, L.; Koekemoer, F.; De Groot, S.; Soole, K.; Langridge, P. Early Flowering as a Drought Escape Mechanism in Plants: How Can It Aid Wheat Production? Front. Plant Sci. 2017, 8, 1950. [CrossRef]

64. Daničić, M.; Zekić, V.; Mirosavljević, M.; Lalić, B.; Putnik-Delić, M.; Maksimović, I.; Marta, A.D. The Response of Spring Barley (Hordeum vulgare L.) to Climate Change in Northern Serbia. Atmosphere 2019, 10, 14. [CrossRef]

65. Schwarz, P.B.; Horsley, R.D.; Schwarz, P.B.; Science, C.; Technology, F.; Horsley, R.D. Malt Quality Improvement in North American Six-Rowed Barley Cultivars Since 1910. J. Am. Soc. Brew. Chem. 1995, 53. [CrossRef]

66. Russell, J.R.; Ellis, R.P.; Thomas, W.T.B.; Waugh, R.; Provan, J.; Booth, A.; Fuller, J.; Lawrence, P.; Young, G.; Powell, W. A Retrospective Analysis of Spring Barley Germplasm Development from "foundation Genotypes" to Currently Successful Cultivars. Mol. Breed. 2000, 6, 553-568. [CrossRef] 